\title{
The Diabetic Foot Research in Arabs’ Countries
}

\author{
Owiss H. Alzahrani, Yousef S. Badahdah, Moataz S. Bamakrid, Abdullah S. Alfayez, \\ Mossab S. Alsaeedi, Amro M. Mansouri, Hasan A. Alzahrani* \\ Mohammed Hussein Al-Amoudi Chair for Diabetic Foot Research, King Abdulaziz University, Jeddah, Saudi Arabia \\ Email: "haaz59@yahoo.com
}

Received April 28, 2013; revised May 28, 2013; accepted June 28, 2013

Copyright (c) 2013 Owiss H. Alzahrani et al. This is an open access article distributed under the Creative Commons Attribution License, which permits unrestricted use, distribution, and reproduction in any medium, provided the original work is properly cited.

\begin{abstract}
Objective: To review all the studies on diabetic foot disorders (DFDs) that were published on the PubMed ${ }^{\circledR}$ site aiming to identify the contributions of the different Arabs' countries in the world scientific literature on this topic. Methods: The PubMed ${ }^{\circledR}$ site was searched using different key words for searching all the abstracts on Diabetes mellitus (DM) and DFDs published from Arabs' League countries $(\mathrm{n}=22)$. For this review, the 22 countries were classified into 3 groups: Group 1 (G1): Gulf Council Countries (GCC) countries ( $n=6$ ), Group 2 (G2): African Arabs' countries ( $n=10)$, Group 3 (G3): Asian and/or Eastern Mediterranean Arabs' countries $(n=6)$. All the abstracts on DM coming from all of the 22 Arabs' countries were initially reviewed to locate the ones related to DFDs' management. All of the articles related to DFDs were reviewed by the senior author. A publication index was created to allow a comparison between the productivity of various countries and correlate that to the population number. Results: By April 2012, a total of 906 articles were published on DM, out of them 115 (11.6\%) were related to DFDs. The largest number of DM/DFDs research came from G1 countries $(n=437 / 51)$ followed by G2 $(n=307 / 38)$ and finally G3 $(n=162 / 26)$. The percentages of the studies related to DFDs were therefore: $11.6 \%, 12.3 \%$ and $20.6 \%$ respectively. Saudi Arabia was the top on the list of all studied countries with 31 studies related to DFDs out of the 187 on DM (16.5\%). Conclusion: More research on DFDs is needed in most of the Arabs' countries particularly those in the GCC region which reported very high prevalence rates and are expected to hold these rates for the coming decades. Also, special attention is needed for those lowincome Arabs' countries that had no contributions in DFDs' research.
\end{abstract}

Keywords: Diabetes Mellitus; Diabetic; Foot; Disorders; Arabs

\section{Introduction}

The term Arabs' countries or Arabs' World usually refers to The Arab League countries which is composed of 22 countries that stretch on two continents (Asia and Africa) on a large geographical area from the Gulf States and Iraq on the eastern side to Morocco and Mauritania on the western side with a total population of approximately 358 million [1]. These countries share common cultural, social, life style backgrounds and speak one language [1]. However, there are few discrepancies between these countries including differences in the economic, political, health systems and the non-communicable diseases prevalence rates [2]. With regard to the non-communicable diseases, most of the Arabs' countries report high rates of type 2 Diabetes mellitus (DM) with a whole range of (21.1\% - 4\%), with the highest rates reported in Kuwait and adjacent Gulf Council Countries (GCC) and the lowest in Somalia [2].

${ }^{*}$ Corresponding author.
According to the International Diabetes Federation (IDF) statistics of 2011, Six Arabs' countries are on the list of the top ten countries that reported highest prevalence rates of DM among 20 - 79-year-old adults globally [3]. These countries in descending order are: Kuwait (21.1\%), Lebanon (20.2\%), Qatar 20.2\%, Saudi Arabia SA 20.0\%, Bahrain (19.9\%) and the United Arab Emirates UAE (19.2\%). These countries are expected to hold their positions on the list of top ten over the coming two decades [4]. In addition, Egypt is the only Arab country on the list of the top ten countries that have the largest number of diabetic patients as it occupies the ninth position on the list with a total number of 7.3 million diabetics in 2011 and that number is expected to increase to reach 12.4 million by year 2030 [3].

Foot disorders are one of the most feared chronic complications of DM [5]. The term diabetic foot disorder DFDs refers to a group of disorders which clinically present with one or more of the following clinical manifestations: foot ulceration, infection, neuropathy, deformity, 
gangrene and/or ischemia [6]. Some of these presentations may overlap in the same patient and frequently on both feet. The reported annual incidence of diabetic foot ulceration varies between $2.1 \%$ to $7.4 \%$ [7] and the lifetime risk of developing a diabetic foot ulcer has been estimated to be as high as $25 \%$ [8]. If not timely and properly managed, the ultimate endpoint of diabetic foot ulcer is amputation in 15\% - 27\% [7,8]. Furthermore, amputation is usually associated with significant morbidity [7] mortality [9], in addition to social, psychological and financial consequences $[7,8,10]$.

Despite of the high prevalence rates of DM and the predicted associated serious complications of DFDs, the published scientific research from the 22 Arabs' countries was not properly reviewed with regard to the volume and/or quality of the publications compared to similar research from other parts of the world. For this reason, all the abstracts on various aspects of diabetic foot disorders (DFDs) management that have been published on the PubMed ${ }^{\circledR}$ [11] site will be reviewed aiming to identify the scientific contributions of the different Arabs' countries in the world literature.

\section{Methods}

For this review, the electronic database of PubMed ${ }^{\circledR}$ site, MEDLINE $^{\circledR}$ was extensively searched for all the studies on DM and DFDs (from 1996 to April 2012). The search strategy was developed from clinical medical subjects' headings (MeSH) and using different text words. Search strings were used alone or in combinations. The searches included the following words and terms: "diabetes", “diabetes mellitus”, “diabetic”, “diabetic foot”, “diabetic foot disorders", "diabetic foot ulcer”, “diabetic foot ulcreation”, “Arab”, “Arabs”, “Arabs countries” and the name of each of the 22 Arabs' states. Six final year medical students of Faculty of Medicine, king Abdulaziz
University conducted the primary research under the supervision of their mentor (HA). For this review, the Arabs' League countries $(n=22)$ were classified into 3 groups: Group 1 (G1): Gulf Council Countries GCC countries $(n=6)$, Group 2 (G2): African Arabs' countries ( $\mathrm{n}=10$ ), Group 3 (G3): Asian and/or Eastern Mediterranean Arabs' countries $(n=6)$. All of the abstracts of the studies on DM coming from all of the Arabs' countries were reviewed to identify those related to DFDs' management. Subsequently, the articles related to DFDs were reviewed by the senior author and a careful review was conducted to find out the total number of studies in each country on DM and on DFDs and that was compared to similar numbers globally. This was followed by finding out the total number of studies in each of the 22 countries. An index for publications on DM per million of the population was created by dividing the total number of publications on DM alone on PubMed ${ }^{\circledR}$ site by the total number of population of each country in million, and a similar index was created for DFDs' research (Tables 1-5). This index was used to limit the bias that may occur on using the total crude number of studies for comparasons between the various regions and countries in view of the wide range in population numbers in Arabs' countries (83.7 - 0.7 million).

\section{Results}

By April 2012, a total of 906 studies were published on the PubMed ${ }^{\circledR}$ site on DM; out of them 115 (11.6\%) were related to DFDs (Table 1). The publication index per million for the studies published on DM was almost 20 times less than the global rate (45.49 globally vs 2.53 in Arabs' countries) whereas the index was clearly better in studies on DFDs (1.23 vs 0.32 respectively) (Table 1).

The largest number of DM/DFDs research came from G1 countries $(n=437 / 51)[5,6,10,12-59]$ followed by G2

Table 1. Contributions of all Arabs' countries to world literature on PubMed site.

\begin{tabular}{cccccc}
\hline Description & $\begin{array}{c}\text { Approximate population } \\
\text { in million }\end{array}$ & $\begin{array}{c}\text { Total number of } \\
\text { publications on DM }\end{array}$ & $\begin{array}{c}\text { Index of publications } \\
\text { on DM per million }\end{array}$ & $\begin{array}{c}\text { Total number of } \\
\text { publications on DFDs }\end{array}$ & $\begin{array}{c}\text { Index of publications } \\
\text { on DFDs per million }\end{array}$ \\
\hline Globally & 7000 & 318,482 & 45.49 & 8612 & 1.23 \\
Arabs & 358.1 & 906 & 2.53 & 115 & 0.32 \\
\hline
\end{tabular}

DFDs: Diabetic Foot Disorders; DM: Diabetes mellitus.

Table 2. Contributions of the three groups of Arabs' countries to world literature as published in PubMed site (in descending order).

\begin{tabular}{cccccc}
\hline Group & $\begin{array}{c}\text { Approximate population } \\
\text { in million }\end{array}$ & $\begin{array}{c}\text { Total number of } \\
\text { publications on DM }\end{array}$ & $\begin{array}{c}\text { Index of publications } \\
\text { on DM per million }\end{array}$ & $\begin{array}{c}\text { Total number of } \\
\text { publications on DFDs }\end{array}$ & $\begin{array}{c}\text { Index of publications } \\
\text { on DFDs per million }\end{array}$ \\
\hline GROUP 1 & 40.8 & 437 & 10.71 & 51 & 1.25 \\
GROUP 2 & 218.9 & 307 & 1.40 & 38 & 0.17 \\
GROUP 3 & 98.4 & 162 & 1.64 & 26 & 0.26 \\
\hline
\end{tabular}

DFDs: Diabetic Foot Disorders; DM: Diabetes mellitus. 
Table 3. Contributions of each country in group 1 countries to world literature as published in PubMed site (in descending order).

\begin{tabular}{|c|c|c|c|c|c|}
\hline Country & $\begin{array}{l}\text { Approximate population } \\
\text { in million }\end{array}$ & $\begin{array}{c}\text { Total number of } \\
\text { publications on DM }\end{array}$ & $\begin{array}{l}\text { Index of publications } \\
\text { on DM per million }\end{array}$ & $\begin{array}{c}\text { Total number of } \\
\text { publications on DFDs }\end{array}$ & $\begin{array}{l}\text { Index of publications } \\
\text { on DFDs per million }\end{array}$ \\
\hline Saudi Arabia & 26.5 & 187 & 7.05 & 31 & 1.16 \\
\hline Kuwait & 2.6 & 102 & 39.23 & 17 & 6.53 \\
\hline United Arab Emirates & 5.3 & 83 & 15.66 & 2 & 0.37 \\
\hline Oman & 3.1 & 43 & 13.87 & 0 & 0.00 \\
\hline Bahrain & 1.2 & 17 & 14.16 & 1 & 0.83 \\
\hline Qatar & 2.0 & 5 & 2.50 & 0 & 0.00 \\
\hline
\end{tabular}

DFDs: Diabetic Foot Disorders; DM: Diabetes mellitus.

Table 4. Contributions of each country in group 2 countries to world literature as published in PubMed site (in descending order).

\begin{tabular}{cccccc}
\hline Country & $\begin{array}{c}\text { Approximate population } \\
\text { in million }\end{array}$ & $\begin{array}{c}\text { Total number of } \\
\text { publications on DM }\end{array}$ & $\begin{array}{c}\text { Index of publications } \\
\text { on DM per million }\end{array}$ & $\begin{array}{c}\text { Total number of } \\
\text { publications on DFDs }\end{array}$ & $\begin{array}{c}\text { Index of publications } \\
\text { on DFDs per million }\end{array}$ \\
\hline Egypt & 83.7 & 117 & 1.39 & 24 & 0.28 \\
Tunisia & 10.7 & 69 & 6.44 & 0 & 0.00 \\
Sudan & 34.2 & 52 & 1.52 & 2 & 0.20 \\
Morocco & 32.3 & 24 & 0.74 & 2 & 0.06 \\
Libya & 5.6 & 24 & 4.28 & 3 & 0.35 \\
Algeria & 37.4 & 15 & 0.40 & 0 & 0.08 \\
Mauritania & 3.4 & 4 & 1.17 & 0 & 0.00 \\
Somalia & 10.0 & 1 & 0.10 & 0 & 0.00 \\
Djibouti & 0.8 & 0 & 1 & 0.00 & 0 \\
Comoros & 0.7 & & 1.42 & 0.00 \\
\hline
\end{tabular}

DFDs: Diabetic Foot Disorders; DM: Diabetes mellitus.

Table 5. Contributions of each country in group 3 countries to world literature as published in PubMed site (in descending order).

\begin{tabular}{cccccc}
\hline Country & $\begin{array}{c}\text { Approximate population } \\
\text { in million }\end{array}$ & $\begin{array}{c}\text { Total number of } \\
\text { publications on DM }\end{array}$ & $\begin{array}{c}\text { Index of publications } \\
\text { on DM per million }\end{array}$ & $\begin{array}{c}\text { Total number of } \\
\text { publications on DFDs }\end{array}$ & $\begin{array}{c}\text { Index of publications } \\
\text { on DFDs per million }\end{array}$ \\
\hline Lebanon & 4.1 & 64 & 15.60 & 13 & 3.17 \\
Jordan & 6.5 & 57 & 8.76 & 9 & 1.38 \\
Palestine & 9.3 & 27 & 2.90 & 0 & 0.00 \\
Iraq & 31.1 & 18 & 0.57 & 4 & 0.12 \\
Yemen & 24.8 & 10 & 0.40 & 0 & 0.00 \\
Syria & 22.5 & 4 & 0.17 & 0 & 0.00 \\
\hline
\end{tabular}

DFDs: Diabetic Foot Disorders; DM: Diabetes mellitus.

(n = 307/38) [60-97] and finally G3 $(\mathrm{n}=162 / 26)$ [98123]. The percentages of the studies related to DFDs were therefore: $11.6 \%, 12.3 \%$ and $20.6 \%$ respectively. The G1 was ahead of the other 2 groups in the total number of publications and had also better publication index per million both in research conducted on DM and
DFDs (10.7 and 1.2 respectively) (Table 2).

The contributions of various G1 countries in the literature indicated that Saudi Arabia was top on the list of all studied countries with 31 studies related to DFDs out of the 187 on DM (16.5\%) followed by Kuwait. However, the Kuwait's index of publications per million was 
clearly the highest among this group both in research conducted on DM and DFDs. However, two of the G1 countries did not report any study on DFDs on PubMed namely Oman and Qatar (Table 3).

In G2 countries, the contributions of various G2 countries indicated that Egypt was on top of the list of G2 with 24 studies related to DFDs out of the 117 on DM (20.5\%) followed by Tunisia. However, the Libya's index of publications per million was higher than both Egypt and Tunisia in the research conducted DFDs, whereas Tunisia's index was the best in DM research (Table 4). Four countries in this African group did not report any study on DFDs (Table 4).

Finally, the contributions of various G3 countries in the literature indicated that Lebanon was on top of the list of all countries in G3 with 13 studies related to DFDs out of the 64 on DM (20.5\%) followed by Jordan. The Lebanon's index of publications per million was also the highest among this group in both in research conducted on DM and DFDs. Three countries in G3 did not report any study on DFDs, Table 5.

On reviewing the designs of the studies, we did not find any randomized controlled trials. Only one was a systematic review from Kuwait by Matowe et al. in 2004 [48]. However, there were a total of 10 prospective cohort studies and 13 case-control studies. The remaining of the published studies were cross-sectional, retrospective, reviews, case reports and letters.

\section{Discussion}

This review shows that in spite of the high prevalence rates of DM and associated complications in Arabs' countries, the rates of published scientific research in one of the most popular research sites namely PubMed ${ }^{\circledR}$, are far lower than similar global rates both in quantity and quality. The United Nations Resolution 61/225, that has been already adopted unanimously in 2006, recognized diabetes as a serious and costly disease that poses a threat to individual well-being and economic progress, especially in low- and middle-income countries [124]. It also addressed the problems of data accuracy in less-developed countries and absence of transparency and national well-designed community studies [124]. Scientific research is therefore crucial to overcome these problems in all countries and particularly those countries that witness high prevalence rates such as many Arabs' countries. The current data clearly demonstrate the timely need for encouraging researchers in all Arabs' countries to have wider contribution in the world literature both in quantity and quality. The Arabs' contribution in DM's research as displayed on PubMed ${ }^{\circledR}$ is less by 20 times compared to the global rate. In contrast, their contributions in DFDs' research are relatively better, but still 3 times less than the global rate. However, the quality of research is not optimum as only one study is a systematic review [48], approximately one third of the studies gives level 3 evidence and the remaining gives level 4 evidence.

When it comes to the inter-regional differences between Arabs' countries in DFDs' research by total numbers of studies, The G1 countries $(n=6)$ are ahead of the other Arabs' countries $(n=16)$. Saudi Arabia is on the top of Arabs' countries in the total number of studies on DFDs $(\mathrm{n}=31)$, followed by Egypt $(\mathrm{n}=24)$ and Kuwait $(n=17)$. However, it seems that Kuwait is ahead of SA if the populations' numbers were taken in consideration as it reported the highest publication's index-as defined here-in all of the Arabs' countries. In G2 countries Egypt is on the top in total number, whereas Libya has relatively better publication's index. In G3, Lebanon occupies the first place on the list of contributions in DFDs' followed by Jordan.

There were total of 10 out of the 22 countries that did not have a single publication displayed on PubMed $^{\circledR}$ site; Oman and Qatar in G1; Tunisia, Mauritania, Somalia, Djibouti and Comoros in G2; Syria, Yemen and Palestine in G3. The lack of contribution in the low-income countries may be justified but this observation is difficult to be understood in an oil producing country such as Qatar.

There are several limitations of the current review that make it a rather pilot initial thematic review than a well designed comprehensive systematic review. Limitations also include limiting our search to one database namely PubMed $^{\circledR}$, some difficulties encountered in securing the original full articles of all the abstracts and the possibility of missing some of the studies published in French speaking North African countries such as Tunisia. These limitations should be taken in consideration in future similar reviews. Nonetheless, we believe that the current review serves its purpose of initial probing of the Arabs' contributions in DFDs' research. It may be considered as the first step in having more comprehensive future reviews in all and each of the 22 Arabs' countries.

\section{Conclusion}

More research on DFDs is needed in most of the Arabs' countries particularly those in the GCC region which reported very high prevalence rates and are expected to hold these rates in the coming few decades. Also, special attention is needed for those low-income Arabs' countries that had no contributions in DFDs' research. Improvements should focus not only on quantity but also focus on the quality of the studies.

\section{Acknowledgements}

The author would like to thank Sheikh "Mohammad Hussein Al-Amoudi Chair for Diabetic Foot Research” at 
King Abdulaziz University for supporting of this study.

\section{REFERENCES}

[1] The Central Intelligence Agency, "The World Fact Book,” 2012.

https://www.cia.gov/library/publications/the-world-factbo ok/rankorder/rankorderguide.html

[2] M., Badran and I. Laher, "Type II Diabetes Mellitus in Arabic-Speaking Countries,” International Journal of Endocrinology, Vol. 2012, 2012, Article ID: 902873. doi:10.1155/2012/902873

[3] “International Diabetes Federation, IDF Atlas,” 2013. http://www.idf.org/diabetesatlas/5e/the-global-burden

[4] S. Wild, G. Roglic, A. Green, R. Sicree and H. King, "Global Prevalence of Diabetes: Estimates for the Year 2000 and Projections for 2030,” Diabetes Care, Vol. 27, No. 5, 2004, pp. 1047-1053. doi:10.2337/diacare.27.5.1047

[5] A. M. Al-Wahbi, "The Diabetic Foot in Arab World," Saudi Medical Journal, Vol. 27, No. 2, 2006, pp. 147153.

[6] F. A. Qari and D. Akbar, "Diabetic Foot: Presentation and Treatment,” Saudi Medical Journal, Vol. 21, No. 5, 2000, pp. 443-446. doi:10.1016/S0140-6736(03)13169-8

[7] W. J. Jeffcoate and K. G. Harding, "Diabetic Foot Ulcers,” Lancet, Vol. 3, No. 361, 2003, pp. 1545-1551. doi:10.1016/S0140-6736(03)13169-8

[8] H. A. Alzahrani, K. Hitos and J. P. Fletcher, "The Diabetic Foot,” Hemi Australian Pty Ltd., Sydney, 2011.

[9] H. A. Alzahrani, N. M. Ghandourah and H. T. Merdad, "Limb Amputations in Western Saudi Arabia," Asian Journal of Surgery, Vol. 15, No.1, 1992, pp. 119-122.

[10] H. A. Alzahrani and M. G. Sehlo, "The Impact of Religious Connectedness on Health-Related Quality of Life in Patients with Diabetic Foot Ulcers," Journal of Religion and Health, Epub Ahead of Print, 2011.

[11] “The National Library of Medicine,” 2013. http://www.ncbi.nlm.nih.gov/pubmed

[12] S. Al Deeb, K. Al Moutaery, M. Arshaduddin, N. Biary and M. Tariq, "Attenuation of Acrylamide-Induced Neurotoxicity in Diabetic Rats," Neurotoxicol Teratol and Teratology, Vol. 22, No. 2, 2000, pp. 247-253.

[13] A. Elsharawy, "Outcome of Midfoot Amputations in Diabetic Gangrene,” Annals of Vascular Surgery, Vol. 25, No. 6, 2011, pp. 778-782. doi:10.1016/j.avsg.2010.11.013

[14] S. Bondokji, M. Rangaswamy, C. Reuter, Y. Farajalla, T. Mole and J. Cockwill, "Clinical Efficacy of a New Variant of a Foam-Based NWPT System,” Journal of Wound Care, Vol. 20, No. 2, 2011, pp. 62, 64-67.

[15] J. S. Alwakeel, A. Al-Suwaida, A. C. Isnani, A. Al-Harbi and A. Alam, "Concomitant Macro and Microvascular Complications in Diabetic Nephropathy," Saudi Journal of Kidney Diseases and Transplantation, Vol. 20, No. 3, 2009, pp. 402-409.

[16] F. A. Zakareia, “Correlation of Peripheral Arterial Blood Flow with Plasma Chemerin and VEGF in Diabetic Pe- ripheral Vascular Disease,” Biomarkers in Medicine, Vol. 6, No. 1, 2012, pp. 81-87. doi:10.2217/bmm.11.85

[17] R. Halawa, A. Karawagh, A. Zeidan, A. E. Mahmoud, M. Sakr and A. Hegazy, "Prevalence of Painful Diabetic Peripheral Neuropathy among Patients Suffering from Diabetes Mellitus in Saudi Arabia," Current Medical Research and Opinion, Vol. 26, No. 2, 2010, pp. 337-343. doi:10.1185/03007990903471940

[18] H. Al-Zahrani, "Role of Vascular Surgery in the Management of Diabetic Foot Problems,” Annals of Saudi Medicine, Vol. 11, No. 6, 1991, pp. 719-720.

[19] A. T. El-Tahawy, "Bacteriology of Diabetic Foot," Saudi Medical Journal, Vol. 21, No. 4, 2000, pp. 344-347.

[20] B. A. Bakhotmah and H. A. Alzahrani, "Self-Reported Use of Complementary and Alternative Medicine (CAM) Products in Topical Treatment of Diabetic Foot Disorders by Diabetic Patients in Jeddah, Western Saudi Arabia," BMC Research Notes, Vol. 6, No. 3, 2010, p. 25. doi:10.1186/1756-0500-3-254

[21] S. A. Qidwai, M. A. Khan, S. R. Hussain and M. S. Malik, "Diabetic Neuroarthropathy," Saudi Medical Journal, Vol. 22, No. 2, 2001, pp. 142-145.

[22] A. Malone, A. Gannass and F. Bowling, "Flexible and Rigid Casting Tape as a Novel Approach to Offloading Diabetic Foot Ulcers,” Journal of Wound Care, Vol. 20, No. 7, 2011, pp. 335-336, 338-339.

[23] A. A. Darwish, A. Reddy, M. Kamal, A. Yaneza and M. M. Al-Teheawy, "Management of Diabetic Foot Lesions with Limited Use of Antibodies," Annals of Saudi Medicine, Vol. 13, No. 1, 1993, pp. 101-103.

[24] R. A. Sulimani, O. O. Famuyiwa and M. O. Mekki, "Pattern of Diabetic Foot Lesions in Saudi Arabia: Experience from King Khalid University Hospital, Riyadh,” Annals of Saudi Medicine, Vol. 11, No. 1, 1991, pp. 47-50.

[25] J. V. Nielsen, "Peripheral Neuropathy, Hypertension, Foot Ulcers and Amputations among Saudi Arabian Patients with Type 2 Diabetes,” Diabetes Research and Clinical Practice, Vol. 41, No. 1, 1998, pp. 63-69. doi:10.1016/S0168-8227(98)00059-X

[26] A. Abolfotouh, S. A. Alfaifi and A. S. Al-Gannas, "Risk Factors of Diabetic Foot in Central Saudi Arabia," Saudi Medical Journal, Vol. 32, No. 7, 2011, pp. 708-713.

[27] U. H. Malabu, K. A. Al-Rubeaan and M. Al-Derewish, "Diabetic Foot Osteomyelitis: Usefulness of Erythrocyte Sedimentation Rate in Its Diagnosis,” West African Journal of Medicine, Vol. 26, No. 2, 2007, pp. 113-116.

[28] H. Al-Doghether, "Improving Foot Examination of Diabetics in Primary Care,” Saudi Medical Journal, Vol. 24, No. 9, 2003, pp. 1029-1030.

[29] M. Malone, A. Gannass and F. Bowling, “A Chronic, Destructive Mycetoma Infection in a Diabetic Foot in Saudi Arabia," The International Journal of Lower Extremity Wounds, Vol. 10, No. 1, 2011, pp. 12-15. doi:10.1177/1534734611400258

[30] M. Al-Qattan, "Lower-Limb Reconstruction Utilizing the Reverse Sural Artery Flap-Gastrocnemius Muscle Cuff Technique,” Annals of Plastic Surgery, Vol. 55, No. 2, 2005, pp. 174-178. 
doi:10.1097/01.sap.0000168888.31085.29

[31] J. S. Al-Wakeel, D. Hammad, A. Al Suwaida, A. H. Mitwalli, N. A. Memon and F. Sulimani, "Microvascular and Macrovascular Complications in Diabetic Nephropathy Patients Referred to Nephrology Clinic," Saudi Journal of Kidney Diseases and Transplantation, Vol. 20, No. 1, 2009, pp. 77-85.

[32] J. A. Al-Tawfiq and J. A. Johndrow, "Presentation and Outcome of Diabetic Foot Ulcers in Saudi Arabian Patients," Advances in Skin \& Wound Care, Vol. 22, No. 3, 2009, pp. 119-121. doi:10.1097/01.ASW.0000305450.33693.f8

[33] F. A. Qari, "Profile of Diabetic Patients with End-stage Renal Failure Requiring Dialysis Treatment at the King Abdulaziz University Hospital, Jeddah,” Saudi Journal of Kidney Diseases and Transplantation, Vol. 13, No. 2, 2002, pp. 199-202.

[34] M. M. Moharram and F. M. Farahat, "Quality Improvement of Diabetes Care Using Flow Sheets in Family Health Practice," Saudi Medical Journal, Vol. 29, No. 1, 2008, pp. 98-101.

[35] H. Akbar, S. A. Mira, T. H. Zawawi and H. M. Malibary, "Subclinical Diabetic Neuropathy: A Common Complication in Saudi Diabetics," Saudi Medical Journal, Vol. 21, No. 5, 2000, pp. 433-437.

[36] A. Al-Moallem, R. M. Zaidan and N. H. Alkali, "The Sympathetic Skin Response in Diabetic Neuropathy and Its Relationship to Autonomic Symptoms," Saudi Medical Journal, Vol. 29, No. 4, 2008, pp. 568-572.

[37] M. Al-Qattan, “The 'Friday Mass' Burns of the Feet in Saudi Arabia,” Burns, Vol. 26, No. 1, 2000, pp. 102-105. doi:10.1016/S0305-4179(99)00097-2

[38] A. M. Al-Wahbi, "Impact of a Diabetic Foot Care Education Program on Lower Limb Amputation Rate," Vascular Health and Risk Management, Vol. 6, 2010, pp. 923934. doi:10.2147/VHRM.S13569

[39] Z. U. Khan, S. Ahmad, E. Mokaddas, R. Chandy, J. Cano and J. Guarro, "Actinomucor elegans var. Kuwaitiensis Isolated from the Wound of a Diabetic Patient," Antonie Van Leeuwenhoek, Vol. 94, No. 3, 2008, pp. 343-352. doi:10.1007/s10482-008-9251-1

[40] K. Shehab, K. F. Al-Jarallah, M. Abraham, O. A. Mojiminiyi, H. Al-Mohamedy and N. A. Abdella, "Back to Basics: Ankle Reflex in the Evaluation of Peripheral Neuropathy in Type 2 Diabetes Mellitus," QJM: An International Journal of Medicine, Vol. 105, No. 4, 2012, pp. 315-320. doi:10.1093/qjmed/hcr212.

[41] A. Abdulrazak, Z. I. Bitar, A. A. Al-Shamali and L. A. Mobasher, "Bacteriological Study of Diabetic Foot Infections," Journal of Diabetes and It's Complications, Vol. 19, No. 3, 2005, pp. 138-141. doi:10.1016/j.jdiacomp.2004.06.001

[42] H. A. Al-Khawari, O. M. Al-Saeed, T. H. Jumaa and F. Chishti, "Evaluating Diabetic Foot Infection with Magnetic Resonance Imaging: Kuwait Experience,” Medical Principles and Practice: International Journal of The Kuwait University, Health Science Center, Vol. 14, No. 3, 2005, pp. 165-172.

[43] S. K. Asfar, M. al-Arouj, A. al-Nakhi, A. Baraka, T. Juma and M. Johny, "Foot Infections in Diabetics: The Antibiotic Choice,” Canadian Journal of Surgery, Vol. 36, No. 2, 1993, pp. 170-172.

[44] S. Bitar, "Glucocorticoid Dynamics and Impaired Wound Healing in Diabetes Mellitus," The American Journal of Pathology, Vol. 152, No. 2, 1998, pp. 547-554.

[45] S. Bitar, "Insulin and Glucocorticoid-Dependant Suppression in the IGF-I System in Diabetic Wounds,” Surgery, Vol. 127, No. 6, 2000, pp. 678-695. doi:10.1067/msy.2000.105869

[46] S. M. Lamloum, L. A. Mobasher, A. H. Karar, L. Basiony, T. H. Abdallah, A. I. Al-Saleh and N. A. Al-Shamali, "Relationship between Postoperative Infectious Complications and Glycemic Control for Diabetic Patients in an Orthopedic Hospital in Kuwait,” Medical Principles and Practice: International Journal of the Kuwait University, Health Science Center, Vol. 18, No. 6, 2008, pp. 447-452. doi:10.1159/000235893

[47] L. Matowe and F. J. Gilbert, "How to Synthesize Evidence for Imaging Guidelines,” Clinical Radiology, Vol. 59, No. 1, 2004, pp. 63-68. doi:10.1016/j.crad.2003.09.002

[48] N. Al-Mutairi, B. I. Eassa and D. A. Al-Rqobah, "Clinical and Mycologic Characteristics of Onychomycosis in Diabetic Patients," Acta Dermatovenerologica Croatica, Vol. 18, No. 2, 2010, pp. 84-91.

[49] J. S. Gondusky, C. J. Gondusky and S. W. Helmers, "Salmonella Osteomyelitis in New-Onset Diabetes Mellitus," Orthopedics, Vol. 32, No. 9, 2009.

[50] M. M. Bager and I. Loutfi, “Optimal Imaging Positions for 3-Phase Bone Scanning of Patients with Bony Pathology of the Feet," Journal of Nuclear Medicine Technology, Vol. 38, No. 2, 2010, pp. 69-75. doi:10.2967/inmt.109.070771

[51] J. M. Al-Hassan, "Diabetic Ulcer Healing Preparations from the Skin of the Arabian Gulf Catfish (Arius bilineartus Val.): A Novel and Effective Treatment," International Journal of Tissue Reactions, Vol. 12, No. 2, 1990, pp. 121-135.

[52] D. Shehab, K. Al-Jarallah, O. A. Mojiminiyi, H. Al Mohamedy and N. A. Abdella, "Does Vitamin D deficiency Play a Role in Peripheral Neuropathy in Type 2 Diabetes?" Diabetic Medicine: A Journal of The British Diabetic Association, Vol. 29, No. 1, 2012, pp. 43-49. doi:10.1111/j.1464-5491.2011.03510.x

[53] A. Al Fadhli, G. Alexander and J. R. Kanjoor, "Versatile Use of Vacuum-Assisted Healing in Fifty Patients," Indian Journal of Plastic Surgery, Vol. 42, No. 2, 2009, pp. 161-168. doi:10.4103/0970-0358.59273.

[54] S. Bitar and Z. N. Labbad, "Transforming Growth FactorBeta and Insulin-Like Growth Factor-I in Relation to Diabetes-Induced Impairment of Wound Healing,” The Journal of Surgical Research, Vol. 61, No. 1, 1996, pp. 113119. doi:10.1006/jsre.1996.0090

[55] K. Al Benwan, A. Al Mulla and V. O. Rotimi, “A Study of the Microbiology of Diabetic Foot Infections in a Teaching Hospital in Kuwait," Journal of Infection and Public Health, Vol. 5, No. 1, 2012, pp. 1-8. doi:10.1016/j.jiph.2011.07.004 
[56] F. Al-Maskari, M. El-Sadig and J. N. Norman, "The Prevalence of Macrovascular Complications among Diabetic Patients in the United Arab Emirates," Cardiovascular Diabetology, Vol. 19, 2007, pp. 6-24. doi:10.1186/1475-2840-6-24

[57] F. Al-Maskari and M. El-Sadig, "Prevalence of Risk Factors for Diabetic Foot Complications,” BMC Family Practice, Vol. 10, 2007, pp. 8-59. doi:10.1186/1471-2296-8-59

[58] F. Al-Mahroos and K. Al-Roomi, "Diabetic Neuropathy, Foot Ulceration, Peripheral Vascular Disease and Potential Risk Factors among Patients with Diabetes in Bahrain: A Nationwide Primary Care Diabetes Clinic-Based Study," Annals of Saudi Medicine, Vol. 26, No. 1, 2007, pp. 25-31. doi:10.4103/0256-4947.51536

[59] M. A. Ayoub, “Ankle Fractures in Diabetic Neuropathic Arthropathy: Can Tibiotalar Arthrodesis Salvage the Limb," The Journal of Bone and Joint Surgery, Vol. 90, No. 7, 2008, pp. 906-914. doi:10.1302/0301-620X.90B7.20090

[60] A. A. Morsy and A. Hosny, "A New System for the Assessment of Diabetic Foot Planter Pressure,” Conference proceedings: Annual International Conference of the IEEE Engineering in Medicine and Biology Society, San Francisco, 1-5 September 2004, pp. 1376-1379.

[61] M. A. Elsharawy, M. Naim and S. Greish, "Human CD34+ Stem Cells Promote Healing of Diabetic Foot Ulcers in Rats," Interactive Cardiovascular and Thoracic Surgery, Vol. 14, No. 3, 2012, pp. 288-293. doi:10.1093/icvts/ivr068

[62] K. A. El-Gafary, K. M. Mostafa and W. Y. Al-Adly, "The Management of Charcot Joint Disease Affecting the Ankle and Foot by Arthrodesis Controlled by an Ilizarov Frame: Early Results," The Journal of Bone and Joint Surgery, Vol. 91, No. 10, 2009, pp. 1322-1325. doi:10.1302/0301-620X.91B10.22431

[63] T. I. Tantawi, K. A. Williams and M. H. Villet, “An Accidental but Safe and Effective Use of Lucilia Cuprina (Diptera: Calliphoridae) in Maggot Debridement Therapy in Alexandria, Egypt," Journal of Medical Entomology, Vol. 47, No. 3, 2010, pp. 491-494. doi:10.1603/ME09183

[64] E. N. Hokkam, “Assessment of Risk Factors in Diabetic Foot Ulceration and Their Impact on the Outcome of the Disease," Primary Care Diabetes, Vol. 3, No. 4, 2009, pp. 219-224. doi:10.1016/j.pcd.2009.08.009

[65] N. A. El Boghdady and G. A. Badr, "Evaluation of Oxidative Stress Markers and Vascular Risk Factors in Patients with Diabetic Peripheral Neuropathy," Cell Bioche-mistry and Function, Vol. 30, No. 4, 2012, pp. 328334. doi:10.1002/cbf.2808

[66] G. M. Saied, R. M. Kamel, A. M. Labib, M. T. Said and A. Z. Mohamed, "The Diabetic Foot and Leg: Combined He-Ne and Infrared Low-Intensity Lasers Improve Skin Blood Perfusion and Prevent Potential Complications, a Prospective Study on 30 Egyptian Patients," Lasers in Medical Science, Vol. 26, No. 5, 2011, pp. 627-632. doi:10.1007/s10103-011-0911-4

[67] H. O. El-Mesallamy, N. M. Hamdy, O. A. Ezzat and A. M. Reda, "Levels of Soluble Advanced Glycation End
Product-Receptors and Other Soluble Serum Markers as Indicators of Diabetic Neuropathy in the Foot,” Journal of Investigative Medicine, Vol. 59, No. 8, 2011, pp. 12331238.

[68] A. H. Yousry and A. M. Abdalhady, "Management of Diabetic Neuropathic Ankle Arthropathy by Arthrodesis Using an Ilizarov Frame,” Acta orthopedica Belgica, Vol. 76, No. 6, 2010, pp. 821-826.

[69] H. Saad Setta, A. Elshahat, K. Elsherbiny, K. Massoud and I. Safe, "Platelet-Rich Plasma versus Platelet-Poor Plasma in the Management of Chronic Diabetic Foot Ulcers: A Comparative Study," International Wound Journal, Vol. 8, No. 3, 2011, pp. 307-312.

[70] M. Elsharawy and E. Elzayat, "A Fast Arterial Duplex Ultrasound Performed by Vascular Surgeons," International Angiology, Vol. 21, No. 4, 2002, pp. 372-378.

[71] M. R. Nahas, H. M. Gawish, M. M. Tarshoby, O. I. State and A. Aboelyazid, "Effect of Simulated Leg Length Discrepancy on Plantar Pressure Distribution in Diabetic Patients with Neuropathic Foot Ulceration,” Journal of Wound Care, Vol. 20, No. 10, 2011, pp. 473-477.

[72] A. M. Moghazy, M. E. Shams, O. A. Adly, A. H. Abbas, M. A. El-Badawy, D. M. Elsakka, S. A. Hassan, W. S. Abdelmohsen, O. S. Ali and B. A. Mohamed, "The Clinical and Cost Effectiveness of Bee Honey Dressing in the Treatment of Diabetic Foot Ulcers," Diabetes Research and Clinical Practice, Vol. 89, No. 3, 2010, pp. 276-281. doi:10.1016/j.diabres.2010.05.021

[73] M. Abdelatif, M. Yakoot and M. Etmaan, "Safety and Efficacy of a New Honey Ointment on Diabetic Foot Ulcers,” Journal of Wound Care, Vol. 17, No. 3, 2008, pp. 108-110.

[74] M. El-Shazly, M. Abdel-Fattah, N. Scorpiglione, M. M. Benedetti, F. Capani, F. Carinci, Q. Carta, D. Cavaliere, E. M. De Feo, C. Taboga, G. Tognoni and A. Nicolucci, "Risk Factors for Lower Limb Complications in Diabetic Patients,” Journal of Diabetes and Its Complications, Vol. 12, No. 1,1998 , pp. 10-17. doi:10.1016/S1056-8727(97)00001-9

[75] T. I. Tantawi, Y. M. Gohar, M. M. Kotb, F. M. Beshara and M. M. El-Naggar, "Clinical and Microbiological Efficacy of MDT in the Treatment of Diabetic Foot Ulcers," Journal of Wound Care, Vol. 16, No. 9, 2007, pp. 379383.

[76] M. A. El-Darouti, S. Hussein, S. R. Al-Tahlawy, M. AlFangary, H. M. Mashaly, E. El-Nabarawy, A. Al-Tawdy, M. Fawzi and R. M. Abdel-Hay, "Clinical Study of Nail Changes in Leprosy and Comparison with Nail Changes in Diabetic Patients," Journal of the European Academy of Dermatology and Venereology, Vol. 25, No. 3, 2011, pp. 290-295.

[77] N. S. Omar, M. R. El-Nahas and J. Gray, "Novel Antibiotics for the Management of Diabetic Foot Infections," International Journal of Antimicrobial Agents, Vol. 31, No. 5, 2008, pp. 411-419.

[78] R. A. Bishara, W. Taha, I. Akladious and M. A. Allam, "Ankle Peak Systolic Velocity: New Parameter to Predict Nonhealing in Diabetic Foot Lesions,” Vascular, Vol. 17, No. 5, 2009, pp. 264-268. doi:10.2310/6670.2009.00032 
[79] A. Mousa, M. Abdel-Hamid, A. Ewida, M. Saad and A. Sahrabi, "Combined Percutaneous Endovascular Iliac Angioplasty and Infrainguinal Surgical Revascularization for Chronic Lower Extremity Ischemia: Preliminary Result,” Vascular, Vol. 18, No. 2, 2010, pp. 71-76. doi:10.2310/6670.2010.00007

[80] M. El-Nahas, H. Gawish, M. Tarshoby and O. State, “The Impact of Topical Phenytoin on Recalcitrant Neuropathic Diabetic Foot Ulceration," Journal of Wound Care, Vol. 18, No. 1, 2009, pp. 33-37.

[81] A. R. El-Ganainy and A. Elgeidi, "Treatment of Distal Femoral Fractures in Elderly Diabetic Patients Using Minimally Invasive Percutaneous Plating Osteosynthesis (MIPPO)," Acta orthopedica Belgica, Vol. 76, No. 4, 2010, pp. 503-506.

[82] M. A. Abu-Youssef, R. Dey, Y. Gohar, A. A. Massoud, L. Ohrstrom and V. Langer, "Synthesis and Structure of Silver Complexes with Nicotinate-Type Ligands Having Antibacterial Activities against Clinically Isolated Antibiotic Resistant Pathogens,” Inorganic Chemistry, Vol. 46, No. 15, 2007, pp. 5893-5903. doi:10.1021/ic0621594

[83] H. E. Bakheit, M. F. Mohamed, S. E. Mahadi, A. B. Widatalla, M. A. Shawer, A. H. Khamis and M. E. Ahmed, "Diabetic Heel Ulcer in the Sudan: Determinants of Outcome," The Journal of Foot and Ankle Surgery: Official Publication of the American College of Foot and Ankle Surgeons, Vol. 51, No. 2, 2012, pp. 152-155.

[84] K. M. Adam, S. M. Mahmoud, S. I. Mahadi, A. H. Widatalla, M. A. Shawer and M. E. Ahmed, "Extended Leg Infection of Diabetic Foot Ulcers: Risk Factors and Outcome,” Journal of Wound Care, Vol. 20, No. 9, 2011, pp. 440-444.

[85] M. ElMakki Ahmed, A. O. Tamimi, S. I. Mahadi, A. H. Widatalla and M. A. Shawer, "Hallux Ulceration in Diabetic Patients," The Journal of Foot and Ankle Surgery: Official Publication of the American College of Foot and Ankle Surgeons, Vol. 49, No. 1, 2010, pp. 2-7. doi:10.1053/j.jfas.2009.07.005

[86] S. M. Mahmoud, A. A. Mohamed, S. E. Mahdi and M. E. Ahmed, "Split-Skin Graft in the Management of Diabetic Foot Ulcers," Journal of Wound Care, Vol. 17, No. 7, 2008, pp. 303-306.

[87] M. E. Ahmed, "Diabetic Septic Foot Lesions in Khartoum,” East African Medical Journal, Vol. 63, No. 3, 1986, pp. 187-190.

[88] I. A. Mohamed, A. R. Ahmed and M. E. Ahmed, "Amputation and Prostheses in Khartoum," Journal of the Royal College of Surgeons of Edinburgh, Vol. 42, No. 4, 1997, pp. 248-251.

[89] A. H. Widatalla, S. E. Mahadi, M. A. Shawer, H. A. Elsayem and M. E. Ahmed, "Implementation of Diabetic Foot Ulcer Classification System for Research Purposes to Predict Lower Extremity Amputation,” International Journal of Diabetes in Developing Countries, Vol. 29, No. 1, 2009, pp. 1-5. doi:10.4103/0973-3930.50707

[90] F. Z. Lamchahab, N. El Kihal, I. Khoudri, A. Chraibi, B. Hassam and M. Ait Ourhroui, "Factors Influencing the Awareness of Diabetic Foot Risks," Annals of Physical and Rehabilitation Medicine, Vol. 54, No. 6, 2011, pp.
359-365. doi:10.1016/j.rehab.2011.07.004

[91] A. Diouri, Z. Slaoui, A. Chadli, H. El Ghomari, M. Kebbou, F. Marouan, A. Farouqi and M. R. Ababou, "[Incidence of Factors Favoring Recurrent Foot Ulcers in Diabetic Patients]," Ann Endocrinol (Paris), Vol. 63, No. 6, 2002, pp. 491-496.

[92] S. Bosseri and G. Gill, "Hand and Foot Sepsis in Libyan Diabetic Patients,” Tropical Doctor, Vol. 27, No. 4, 1997, pp. 232-233.

[93] F. T. Lester, "Hand and Foot Sepsis in Libyan Diabetic Patients,” Tropical Doctor, Vol. 27, No. 4, 1997, p. 195.

[94] A. Benotmane, K. Faraoun, F. Mohammedi, M. E. Amani and T. Benkhelifa, "Treatment of Diabetic Foot Lesions in Hospital: Results of 2 Successive Five-Year Periods, 1989-1993 and 1994-1998," Diabetes \& Metabolism, Vol. 30, No. 3, 2004, pp. 245-250. doi:10.1016/S1262-3636(07)70115-5

[95] A. Benotmane, F. Mohammedi, F. Ayad, K. Kadi, S. Medjbeur and A. Azzouz, "Management of Diabetic Foot Lesions in Hospital: Costs and Benefits," Diabetes \& Metabolism, Vol. 27, No. 6, 2001, pp. 688-694.

[96] A. Benotmane, F. Mohammedi, F. Ayad, K. Kadi and A. Azzouz, "Diabetic Foot Lesions: Etiologic and Prognostic Factors,” Diabetes \& Metabolism, Vol. 26, No. 2, 2000, pp. 113-117.

[97] T. Darst , T. D. Weaver and B. Zangwill, "Charcot's Joint Following Keller Arthroplasty. A Case Report,” Journal of American Podiatric Medical Association, Vol. 88, No. 3, 1998, pp. 140-143.

[98] R. S. Moucharafieh, S. Saghieh, G. Macari and B. Atiyeh, "Diabetic Foot Salvage with Microsurgical Free-Tissue Transfer,” Microsurgery, Vol. 23, No. 3, 2003, pp. 257261. doi:10.1002/micr.10118

[99] J. Sanders, J. M. Robbins and M. E. Edmonds, "History of the Team Approach to Amputation Prevention: Pioneers and Milestones," Journal of American Podiatric Medical Association, Vol. 100, No. 5, 2010, pp. 317-334.

[100] L. J. Sanders, J. M. Robbins and M. E. Edmonds, "History of the Team Approach to Amputation Prevention: Pioneers and Milestones," Journal of Vascular Surgery, Vol. 52, No. 3, 2010, pp. 3S-16S. doi:10.1016/j.jvs.2010.06.002

[101] B. S. Atiyeh, R. E. Sfeir, M. M. Hussein and T. Husami, "Preliminary Arteriovenous Fistula for Free-Flap Reconstruction in the Diabetic Foot," Plastic and Reconstructive Surgery, Vol. 95, No. 6, 1995, pp. 1062-1069. doi:10.1097/00006534-199505000-00017

[102] A. O. Miller and M. Henry, "Update in Diagnosis and Treatment of Diabetic Foot Infections,” Physical Medical Rehabilitation Clinics of North America, Vol. 20, No. 4, 2009, pp. 611-625. doi:10.1016/j.pmr.2009.06.007.

[103] R. Kreidy and E. Hajjar, "Digital Pulse Volume Recording: An Essential Test for the Assessment of Arteritis in Diabetic Patients,” Journal of Medical Libanese, Vol. 45, No. 2, 1997, pp. 73-77.

[104] Y. Y. Cheung, M. Doyley, T. B. Miller, F. Kennedy, F. J. Lynch, J. S. Wrobel, K. Paulson and J. Weaver, "Magnetic Resonance Elastography of the Plantar Fat Pads: 
Preliminary Study in Diabetic Patients and Asymptomatic Volunteers,” Journal of Computer Assisted Tomography, Vol. 30, No. 2, 2006, pp. 321-326. doi:10.1097/00004728-200603000-00031

[105] A. Beydoun, A. Shaibani, M. Hopwood and Y. Wan, “Oxcarbazepine in Painful Diabetic Neuropathy: Results of a Dose-Ranging Study," Acta Neurologica Scandinavica, Vol. 113, No. 6, 2006, pp. 395-404. doi:10.1111/j.1600-0404.2006.00631.x

[106] J. Sanders, "Diabetes Mellitus. Prevention of Amputation," Journal of American Podiatric Medical Association, Vol. 84, No. 7, 1994, pp. 322-328.

[107] R. Musharafieh, B. Atiyeh, G. Macari and R. Haidar, "Radial Forearm Fasciocutaneous Free-Tissue Transfer in Ankle and Foot Reconstruction: Review of 17 Cases," Journal of Reconstructive Microsurgery, Vol. 17, No. 3, 2001, pp. 147-150. doi:10.1055/s-2001-14344

[108] R. Musharafieh, G. Macari, S. Hayek, B. Elhassan and B. Atiyeh, "Rectus Abdominis Free-Tissue Transfer in Lower Extremity Reconstruction: Review of 40 Cases," Journal of Reconstructive Microsurgery, Vol. 16, No. 5, 2000, pp. 341-345. doi:10.1055/s-2000-7343

[109] L. J. Sanders, “The Charcot Foot: Historical Perspective 1827-2003,” Diabetes/Metabolism Research and Review, Vol. 20, Suppl. 1, 2004, pp. S4-S8.

[110] N. A. Younes and A. T. Ahmad, "Diabetic Foot Disease," Endocrine Practice, Vol. 12, No. 5, 2006, pp. 583-592. doi:10.4158/EP.12.5.583

[111] N. A. Younes and F. G. Bakri, "Diabetic Foot Infection," Saudi Medical Journal, Vol. 27, No. 5, 2006, pp. 596603.

[112] N. A. Younes, A. M. Albsoul and H. Awad, "Diabetic Heel Ulcers: A Major Risk Factor for Lower Extremity Amputation," Ostomy Wound Management, Vol. 50, No. 6, 2004, pp. 50-60.

[113] A. D. Al-Ebous, B. Hiasat, M. Sarayrah, M. Al-Jahmi and A. N. Al-Zuriqat, "Management of Diabetic Foot in a Jordanian Hospital," East Mediterranean Health Journal, Vol. 11, No. 3, 2005, pp. 490-493.
[114] E. Fowler, N. Vesely, M. Pelfrey, S. Jordan and T. Amberry, "Managing Diabetic Foot Ulcers," Home Healthcare Nurse, Vol. 17, No. 6, 1999, pp. 357-364. doi:10.1097/00004045-199906000-00005

[115] A. S. Jbour, N. S. Jarrah, A. M. Radaideh, N. S. Shegem, I. M. Bader, A. M. Batieha and K. M. Ajlouni, "Prevalence and Predictors of Diabetic Foot Syndrome in Type 2 Diabetes Mellitus in Jordan,” Saudi Medical Journal, Vol. 24, No. 7, 2003, pp. 761-764.

[116] M. R. Khammash and K. A. Obeidat, "Prevalence of Ischemia in Diabetic Foot Infection," World Journal of Surgery, Vol. 27, No. 7, 2003, pp. 797-799. doi:10.1007/s00268-003-6889-8

[117] J. M. Elrefai, "Prevalence of Neuropathy in the Diabetic Foot,” Neurosciences (Riyadh), Vol. 14, No. 2, 2009, pp. 163-166.

[118] E. Fowler, N. Vesely, M. Pelfrey, S. Jordan and T. Amberry, "Wound Care for Persons with Diabetes," Home Healthcare Nurse, Vol. 17, No. 7, 1999, pp. 437-444. doi:10.1097/00004045-199907000-00008

[119] A. A. Mansour and S. G. Dahyak, “Are Foot Abnormalities More Common in Adults with Diabetes? A CrossSectional Study in Basra, Iraq,” The Permanente Journal, Vol. 12, No. 4, 2008, pp. 25-30.

[120] A. I. Khoshnaw, “The Diabetic Foot in Iraq,” Lancet, Vol. 366, No. 9498, 2005, p. 1718. doi:10.1016/S0140-6736(05)67697-0

[121] A. A. Mansour and H. J. Imran, "Foot Abnormalities in Diabetics: Prevalence \& Predictors In Basrah, Iraq,” $\mathrm{Pa}$ kistan Journal of Medical Sciences, Vol. 22, No. 3, 2006, pp. 229-233.

[122] A. A. Mansour and M. A. Jabber, "Diabetic Foot: Correlation between Clinical Abnormalities and Electrophysiological Studies," Middle East Journal of Family Medicine, Vol. 5, No. 6, 2007, pp. 13-16.

[123] “The United Nations,” 2011. http://www.un.org/Docs/journal/asp/ws.asp?m=A/RES/61/ 